\title{
Influence of particle size and sources of non-starch polysaccharides on postprandial glycaemia, insulinaemia and triacylglycerolaemia in pigs and starch digestion in vitro
}

\author{
BY CHRISTOPHE LECLERE', DENIS LAIRON ${ }^{2}$, MARTINE CHAMP \\ AND CHRISTINE CHERBUT \\ ${ }^{1}$ Institut National de la Recherche Agronomique, Laboratoire de Technologie Appliquée à la \\ Nutrition, B.P. 527, 44026 Nantes Cédex 03, France \\ ${ }^{2}$ Institut National de la Santé et de la Recherche Médicale, U-130, 18, Avenue Mozart, \\ 13009 Marseille, France
}

(Received 24 October 1991-Accepted 7 September 1992)

\begin{abstract}
Physico-chemical properties of dietary fibres might be involved in metabolic control, particularly of the postprandial blood glucose response. The aim of the present study was to look at the effects of the content of soluble fibres and of the particle size of solid fibres on in vitro and in vivo starch hydrolysis and on the subsequent glucose absorption as well as the triacylglycerolaemia. Two sources of dietary fibres, one, with soluble fibres (beet pulp), the other with mostly insoluble fibres (wheat bran), were added at the rate of $60 \mathrm{~g} / \mathrm{kg}$ to a meal simulating human food. The fibre sources were ground in order to obtain two different particle sizes $(250$ and $500 \mu \mathrm{m})$. Beet pulp decreased significantly $(P<0.05)$ initial in vitro hydrolysis whereas wheat bran increased starch hydrolysis in the first $10 \mathrm{~min}$. Wheat bran and beet pulp, whatever its particle size, lowered the post-prandial triacylglycerol response. No significant effect was found with dietary fibre-supplemented diets on postprandial glycaemic and insulinaemic values. High correlation was found between initial in vitro starch hydrolysis and mean areas under the insulinaemic curves. This in vitro model can be used to predict initial in vivo digestion of carbohydrates from complex foods.
\end{abstract}

Non-starch polysaccharides: Starch hydrolysis: Blood biochemistry: Pig

Non-starch polysaccharides (NSP) have been shown to reduce gastrointestinal transit time, plasma total cholesterol concentration and postprandial glucose concentrations, and may, therefore, be beneficial to health (Wyman et al. 1976; Jenkins et al. 1978; Anderson et al. 1979; Anderson \& Tietyen-Clark, 1986). These effects may be associated with five physicochemical properties of NSP: fermentability, ion-exchange capacity, water-holding capacity, viscosity and solubility (Jenkins et al. 1978; Blackburn et al. 1984; Cherbut et al. 1991; Goodlad \& Mathers, 1991). Thus, viscous soluble NSP can influence postprandial glycaemia and insulinaemia in healthy and non-insulin dependent diabetic subjects (Jenkins et al. 1978; Edwards et al. 1987; Ebeling et al. 1988; Hamberg et al. 1989; Karlstrom et al. 1989). Effects on blood lipids seem to differ according to the solubility of NSP. Insoluble NSP may influence fat digestion by interacting with lipase (EC 3.1.1.3) (Schneeman, 1978; Gallaher \& Schneeman, 1985; Lairon et al. 1985; Borel et al. 1989, 1990), while soluble NSP may influence fat absorption through viscosity effects (Gee et al. 1983). Soluble NSP reduce plasma cholesterol; they usually do not influence triacylglycerols (Anderson \& Tietyen-Clark, 1986); this may (Leveille \& Sauberlich, 1966; Kay \& Truswell, 1977) or may not (Anderson et al. 1984) be accompanied by enhanced faecal excretion of bile acids. 
The effect of particle size of NSP on postprandial glycaemia, insulinaemia and triacylglycerolaemia could be mediated through the properties of dietary fibres. These properties, viscosity, water-holding capacity, ion-exchange capacity or fermentability, change when the particle size changes (Peter et al. 1991). Heaton et al. (1988) found that as the particle size of wheat flours was reduced, starch digestibility in vitro was increased but the correlation with effects on blood glucose and insulin levels of healthy subjects was low. Reducing the size of wheat-bran particles led to progressive increases in the inhibition of pancreatic lipase in vitro (Lairon et al. 1985).

The objective of the present study was to investigate the effect of the particle size of two different dietary fibre sources, one rich in insoluble fibres (wheat bran), the other rich in soluble fibres (sugar-beet pulp) on in vivo blood glucose, insulin and triacylglycerol levels in the pig and on in vitro hydrolysis of starch, when these dietary fibres were present in a diet.

\section{MATERIALS AND METHODS \\ Material}

Wheat bran, provided by the Bret-Aubert Company (Ancenis, France), was ground to two mean particle sizes, 250 and $500 \mu \mathrm{m}$. Dried beet pulp (SRD Laboratory, Compiègne, France) had a $500 \mu \mathrm{m}$ mean particle size. Part of it was ground to obtain sugar-beet pulp with a mean size of $250 \mu \mathrm{m}$.

\section{Preparation and composition of the diets}

Dietary fibre sources were incorporated $(60 \mathrm{~g} / \mathrm{kg}$ total diet) into a semi-synthetic diet containing ( $\mathrm{g} / \mathrm{kg}$ diet): mashed potatoes 653 (Vico, Braine, France), fish-meal 127 (Lorientaise des Produits de la Pêche, Lorient, France), maize oil 40, lard 150 and mineral and vitamin supplement 30 . Energy was provided from fat $(35.5 \%)$, carbohydrate $(54.0 \%)$ and protein $(10.5 \%)$. This diet, rich in fat and containing a source of cooked starch, was supposed to simulate human food. These diets were used for both in vitro and in vivo studies.

\section{Methods}

The starch content of fibre sources and mixed foods was determined by an enzymatic u.v. method of Boehringer (Mannheim, ref. 207748). This method comprises the following main steps: solubilization of starch with dimethylsulphoxide, digestion with amyloglucosidase (EC 3.2.1.3) at $37^{\circ}$ and free glucose measurement using the combined hexokinase (EC 2.7.1.1)-glucose-6-phosphate dehydrogenase (EC 1.1.1.49) u.v. assay. Total soluble and insoluble fibres were analysed in accordance with the Association of Official Analytical Chemists method described by Prosky et al. (1988).

Postprandial glucose level was estimated by a glucose oxidase (EC 1.1.3.4) method. Insulin concentration was determined by radioimmunoassay and triacylglycerols were assayed by an enzymic method (Buccolo \& David, 1973).

In vitro starch hydrolysis was carried out with a porcine pancreatic $\alpha$-amylase (EC 3.2.1.1; Merck, 16312) according to Leclere et al. (1990). Starch digestion was measured with and without the addition of porcine pancreatic $\alpha$-amylase to a fibre-free diet (FF) and to diets with $60 \mathrm{~g} / \mathrm{kg}$ wheat bran (WB) or beet pulp (BP) of two different particle sizes: $500 \mu \mathrm{m}$ (WB1 and BP1) or $250 \mu \mathrm{m}$ (WB2 and BP2).

Incubation medium $(5 \mathrm{ml})$ was taken just before the addition of the porcine pancreatic $\alpha$-amylase and also at 2, 5, 7, 10, 20, 40,60, 90 and $120 \mathrm{~min}$ after this addition. For each point of the starch hydrolysis curve, starch hydrolysis, expressed as a percentage of the initial starch, was obtained by subtracting the initial amount of soluble sugars in the diet 
Table 1. Starch and fibre composition $(\mathrm{g} / \mathrm{kg})$ of wheat bran (WBI and WB2) and sugarbeet pulp (BPI and BP2)*

(Mean values with their standard errors for three measurements)

\begin{tabular}{|c|c|c|c|c|c|c|c|}
\hline \multirow{3}{*}{$\begin{array}{l}\text { Fibre } \\
\text { source }\end{array}$} & \multirow{3}{*}{$\begin{array}{c}\text { Average } \\
\text { particle size } \\
(\mu \mathrm{m})\end{array}$} & \multicolumn{4}{|c|}{ Fibres } & & \\
\hline & & \multicolumn{2}{|c|}{ Soluble } & \multicolumn{2}{|c|}{ Insoluble } & \multicolumn{2}{|c|}{ Starch } \\
\hline & & Mean & $\mathrm{SE}$ & Mean & $\mathrm{SE}$ & Mean & SE \\
\hline BP1 & 500 & 110 & 11 & 801 & 19 & \multicolumn{2}{|c|}{ ND } \\
\hline $\mathrm{BP} 2$ & 250 & 180 & 30 & 737 & 13 & \multicolumn{2}{|c|}{ ND } \\
\hline WB 1 & 500 & 39 & 11 & 513 & 11 & 131 & 01 \\
\hline WB2 & 250 & 44 & 03 & 543 & 04 & 128 & 04 \\
\hline
\end{tabular}

ND, not determined.

* For details of experimental diets and procedures, see p. 180.

from the total sugar content. This hydrolysis was repeated on the whole set of samples of 3 different $\mathrm{d}$.

\section{Animals}

Six Large-White male growing pigs were used for the experiment. Pigs were 3 months old and weighed about $30 \mathrm{~kg}$ at the beginning of the experiment. They were fasted for $16 \mathrm{~h}$ prior to being given the test meal. The animals ate $500 \mathrm{~g}$ diet with $1.5 \mathrm{l}$ water. They received the five diets in a random order successively: fibre-free (FF) and supplemented with $60 \mathrm{~g}$ fibre $/ \mathrm{kg}$ (WB1, WB2, BP1, BP2). There was a delay of more than $48 \mathrm{~h}$ between each test day. Pigs were previously equipped with a permanent catheter in the jugular vein, in order to collect the peripheral blood. Blood was collected at the following time points: 15 min before the meal, just before the meal, and then at $15,30,45,60,75,90,120,150,180,240$, 270,330 and $390 \mathrm{~min}$. Plasma was prepared by centrifugation $(9000 \mathrm{~g}, 10 \mathrm{~min})$.

\section{Statistical analysis}

One-way analysis of variance was used to compare in vitro starch hydrolysis results between diets, $P<0.05$ being regarded as significant. One-way analysis of variance for repeated measures was used to compare glucose, insulin and triacylglycerol levels and areas between diets.

\section{RESULTS}

\section{Chemical characterization of dietary fibres}

Total, insoluble and soluble fractions of fibres of both fibre sources and the starch content of wheat bran are given in Table 1. Finely-ground dietary fibre had the same total fibre content as the initial product; however, the soluble fibre was in larger concentrations in finely-ground beet pulp than in raw beet pulp $(180 v .110 \mathrm{~g}$ dry matter $/ \mathrm{kg}, P<0.05)$. On the contrary, or as a consequence, the raw beet pulp exhibited a higher insoluble fibre content than the finest pulp did $(801 v .737 \mathrm{~g} / \mathrm{kg}, P<0.01)$. Whereas the soluble fibre content of both wheat bran preparations showed no significant differences, the insoluble fibre content increased when the wheat bran was finely ground $(513 v .543 \mathrm{~g} / \mathrm{kg}, P<0.05)$.

\section{In vitro starch digestion}

With no $\alpha$-amylase addition, starch of the fibre-free (FF) or pulp supplemented (BP) diets was not hydrolysed during the $2 \mathrm{~h}$ of incubation (Fig. 1). On the contrary, starch of the 


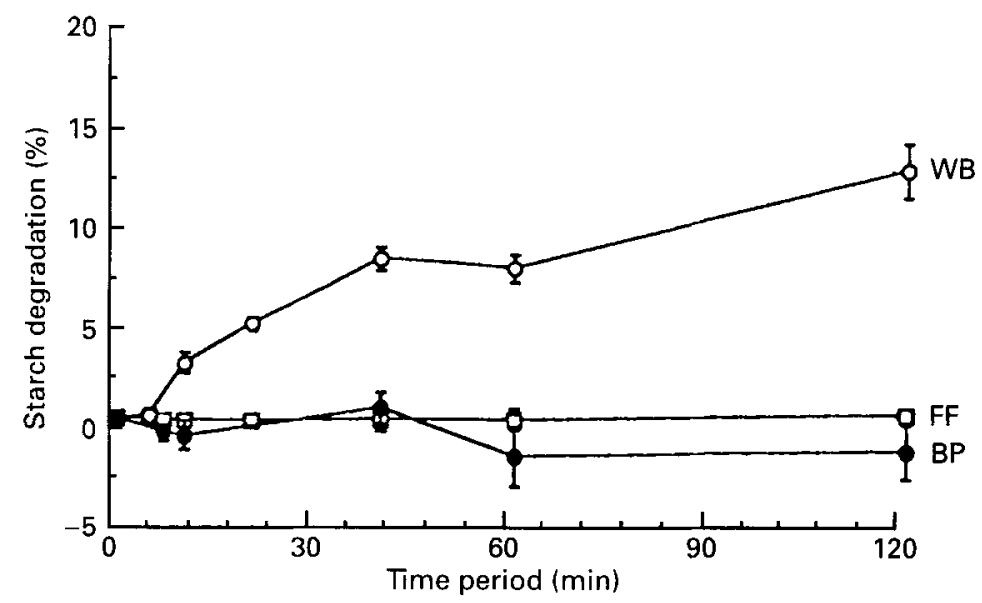

Fig. 1. Starch degradation of diets for $2 \mathrm{~h}$ without pancreatic $\alpha$-amylase $(E C 3.2 .1,1)$ addition (expressed as $\%$ starch hydrolysed compared with initial starch present in the diets; $n 6$; mean \pm SEM); FF, fibre-free diet; WB, mean of 250 and $500 \mu \mathrm{m}$ wheat bran-supplemented diets; BP, mean of 250 and $500 \mu \mathrm{m}$ sugar-beet pulpsupplemented diets.

Table 2. In vitro starch degradation (\%) using $300 \mathrm{IU} / \mathrm{mg}$ hog pancreatic amylase $(E C 3.2 .1 .1)^{*}$

\begin{tabular}{|c|c|c|c|c|c|c|}
\hline \multirow{2}{*}{$\begin{array}{l}\text { Time } \\
\text { (min) }\end{array}$} & \multicolumn{5}{|c|}{$\operatorname{Diet} \uparrow$} & \multirow[b]{2}{*}{$\mathrm{SE}$} \\
\hline & $\mathrm{FF}$ & BP1 & BP2 & WB1 & WB2 & \\
\hline 2 & $15 \cdot 02^{\mathrm{a}}$ & $8 \cdot 39^{\mathrm{b}}$ & $11 \cdot 46^{\mathrm{ab}}$ & $34 \cdot 77^{\mathrm{e}}$ & $34.93^{\mathrm{C}}$ & 1.69 \\
\hline 5 & $29 \cdot 13^{\mathrm{a}}$ & $25 \cdot 71^{\mathrm{a}}$ & $28 \cdot 25^{\mathrm{a}}$ & $41 \cdot 01^{b}$ & $42 \cdot 81^{b}$ & 1.95 \\
\hline 7 & $35 \cdot 20^{\mathrm{a}}$ & $28 \cdot 66^{\mathrm{b}}$ & $32.89^{\circ}$ & $44 \cdot 43^{d}$ & $45 \cdot 39^{d}$ & 0.63 \\
\hline 10 & $42 \cdot 42^{a}$ & $37 \cdot 22^{b}$ & $38 \cdot 13^{b}$ & $48 \cdot 05^{\mathrm{d}}$ & $49 \cdot 93^{d}$ & $1 \cdot 26$ \\
\hline 20 & $52 \cdot 80^{\mathrm{ab}}$ & $48 \cdot 38^{\mathrm{a}}$ & $48 \cdot 20^{\mathrm{a}}$ & $54 \cdot 74^{b}$ & $52 \cdot 21^{\mathrm{ab}}$ & $2 \cdot 30$ \\
\hline 40 & $59 \cdot 63^{a}$ & $56.77^{\text {he }}$ & $55 \cdot 33^{b}$ & $58 \cdot 13^{\mathrm{ac}}$ & $58 \cdot 61^{\mathrm{acc}}$ & 0.88 \\
\hline 60 & $61.88^{a b}$ & $62 \cdot 54^{b}$ & $58 \cdot 78^{\mathrm{ac}}$ & $55.49^{c}$ & $57 \cdot 88^{\circ}$ & $1 \cdot 12$ \\
\hline 90 & $62 \cdot 04$ & $62 \cdot 44$ & $61 \cdot 76$ & $60 \cdot 04$ & $57 \cdot 59$ & $2 \cdot 37$ \\
\hline 120 & $65 \cdot 36$ & $62 \cdot 49$ & 63.64 & $64 \cdot 97$ & $63 \cdot 37$ & $1 \cdot 47$ \\
\hline
\end{tabular}

FF, fibre-free diet; BP1 and BP2, sugar-beet pulp-supplemented diets; WB1 and WB2, wheat bransupplemented diets.

Values with unlike superscript letters for the same time were significantly different (one-way analysis of variance, $P<0.05$ ).

* For details of experimental procedures, see pp. 180-181.

$\dagger$ For details of experimental diets, see p. 180.

wheat-bran-supplemented (WB) diets was slightly degraded in in vitro test conditions: about $130 \mathrm{~g}$ starch $/ \mathrm{kg}$ diet was hydrolysed, after $2 \mathrm{~h}$, by endogenous $\alpha$-amylases of wheat bran.

Starch degradation by the pancreatic $\alpha$-amylase was significantly higher in the case of the fibre-free diet than with the beet-pulp diets for both BP1 and BP2 at the 7th, 10th and 40 th min and at the 60th min with BP2 (Table 2). The grinding of beet pulp and consequently the increase of the soluble: insoluble fibre ratio, did not modify in vitro starch degradation, except at two time points between BP1 and BP2.

Initial starch degradation was significantly higher with both wheat-bran diets than with the other diets, although it became less significant from the 10th min onwards up to the 
Table 3. Characteristics of metabolic responses during the postprandial period*

\begin{tabular}{|c|c|c|c|c|c|c|}
\hline & \multicolumn{5}{|c|}{ Diet $†$} & \multirow[b]{2}{*}{$\mathrm{SE}$} \\
\hline & FF & BPI & $\mathrm{BP} 2$ & WB1 & WB2 & \\
\hline \multicolumn{7}{|l|}{ Glucose } \\
\hline Peaking time (min) & 35 & 33 & 30 & 25 & 27 & 5 \\
\hline $\begin{array}{l}\text { Delta peak above } \\
\text { fasting value }(\mathrm{mmol} / \mathrm{l})\end{array}$ & $1 \cdot 7^{\mathrm{a}}$ & $1 \cdot 2^{\mathrm{b}}$ & $1 \cdot 5^{\mathrm{ab}}$ & $1 \cdot 3^{\mathrm{ab}}$ & $1 \cdot 5^{\mathrm{ab}}$ & 0.2 \\
\hline \multicolumn{7}{|l|}{$\begin{array}{l}\text { Area under curve } \\
(\mathrm{mmol} / 1 \text { per min })\end{array}$} \\
\hline 0-60 min & $47 \cdot 5$ & $23 \cdot 5$ & $37 \cdot 3$ & $34 \cdot 1$ & $51 \cdot 6$ & $9 \cdot 9$ \\
\hline $0-90 \mathrm{~min}$ & $67 \cdot 2$ & $33 \cdot 9$ & $53 \cdot 8$ & $48 \cdot 1$ & $70 \cdot 1$ & $13 \cdot 8$ \\
\hline $0-120 \mathrm{~min}$ & $150 \cdot 3$ & 97.9 & $134 \cdot 8$ & 114.9 & $157 \cdot 3$ & $29 \cdot 4$ \\
\hline \multicolumn{7}{|l|}{ Insulin } \\
\hline Peaking time (min) & 38 & 40 & 43 & 40 & 40 & 7 \\
\hline $\begin{array}{l}\text { Delta peak above } \\
\text { fasting value }(\mathrm{nmol} / \mathrm{l})\end{array}$ & 0.49 & $0 \cdot 38$ & 0.49 & $0 \cdot 39$ & 0.47 & $0 \cdot 1$ \\
\hline \multicolumn{7}{|l|}{$\begin{array}{l}\text { Area under curve } \\
(\mathrm{nmol} / 1 \text { per min) }\end{array}$} \\
\hline $0-60 \mathrm{~min}$ & $14 \cdot 4$ & $10 \cdot 6$ & 11.9 & $13 \cdot 2$ & $15 \cdot 1$ & $3 \cdot 1$ \\
\hline $0-90 \mathrm{~min}$ & $18 \cdot 6$ & $14 \cdot 5$ & $17 \cdot 0$ & $17 \cdot 9$ & $19 \cdot 1$ & $3 \cdot 7$ \\
\hline $0-120 \mathrm{~min}$ & $27 \cdot 8$ & $24 \cdot 4$ & $26 \cdot 5$ & $30 \cdot 2$ & $31 \cdot 3$ & $5 \cdot 6$ \\
\hline \multicolumn{7}{|l|}{ Triacylglycerol } \\
\hline Peaking time (min) & $173^{\mathrm{a}}$ & $240^{\mathrm{b}}$ & $220^{\mathrm{ab}}$ & $218^{\mathrm{ab}}$ & $218^{a b}$ & 15 \\
\hline $\begin{array}{l}\text { Delta peak above } \\
\text { fasting value (mmol/l) }\end{array}$ & $20 \cdot 3^{a}$ & $18 \cdot 6^{\mathrm{ab}}$ & $10 \cdot 2^{\mathrm{b}}$ & $11 \cdot 8^{\mathrm{b}}$ & $13 \cdot 3^{\mathrm{ab}}$ & $2 \cdot 8$ \\
\hline \multicolumn{7}{|l|}{$\begin{array}{l}\text { Area under curve } \\
(\mathrm{mmol} / 1 \text { per } \mathrm{min})\end{array}$} \\
\hline $0-150 \mathrm{~min}$ & $31 \cdot 4^{a}$ & $5.9^{b}$ & $5 \cdot 8^{b}$ & $15 \cdot 7^{\mathrm{ab}}$ & $14 \cdot 4^{\mathrm{ib}}$ & 5.6 \\
\hline $0-210 \mathrm{~min}$ & $67.9^{\mathrm{a}}$ & $29 \cdot 5^{b}$ & $23 \cdot 2^{\mathrm{b}}$ & $36 \cdot 3^{\mathrm{b}}$ & $33 \cdot 8^{b}$ & $9 \cdot 4$ \\
\hline $0-270 \mathrm{~min}$ & $92 \cdot 0^{\mathrm{a}}$ & $54 \cdot 1^{\text {an }}$ & $36 \cdot 2^{b}$ & $51 \cdot 2^{b}$ & $52 \cdot 9^{\mathrm{b}}$ & $12 \cdot 2$ \\
\hline
\end{tabular}

FF, fibre-free diet; BP1 and BP2, sugar-beet pulp-supplemented diets; WB1 and WB2, wheat bransupplemented diets.

a.b Values with unlike superscript letters for the same time were significantly different (one-way analysis of variance for repeated measures, $P<0 \cdot 05$ ).

* For details of experimental procedures, see pp. 180-181.

$\uparrow$ For details of experimental diets, see p. 180 .

40th min of the starch degradation. Moreover, wheat-bran diets exhibited lower rates of starch degradation at the 60 th min.

\section{Experiments in vivo}

For the metabolic variables, the total area under the curve, which is the mean integrated level, showed significant differences between diets that did not appear with the raw values because of the high individual variations between animals.

Plasma glucose levels and the total area under the curves were not significantly different between all diets, except with BPl which exhibited a lower peak value than FF (Table 3). No time delay in the appearance of the peak was observed between diets.

Insulin curve profiles after the meal intake were not different for all diets. Plasma insulinaemic levels and the total area under the curves were not significantly different between all diets (Table 3 ).

After all test meals, triacylglycerol values rose gradually. Nevertheless, it seemed that the postprandial peak appeared later with diets including fibres, especially in the cases of test 


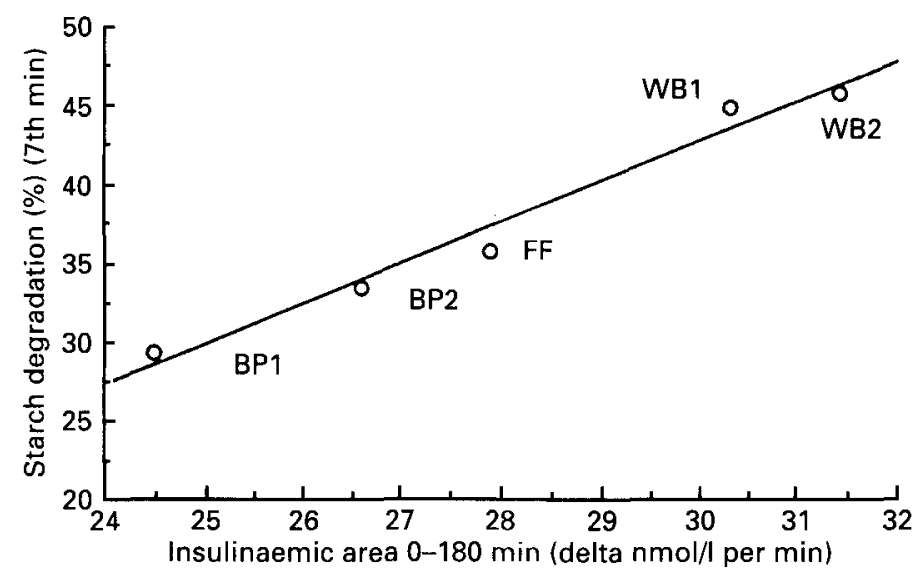

Fig. 2. Correlation between the proportion of in vitro starch hydrolysis at the 7 th min and mean areas under the $0-180 \mathrm{~min}$ plasma insulinaemic variations; $R^{2} 0.98$.

meals enriched either with finely ground beet pulp or wheat bran. Compared with the control test meal, triacylglycerol values were significantly lower with BP2 between 15 and $255 \mathrm{~min}$. At some time points, triacylglycerol concentrations obtained with BP1, WB2 and WB1 were also significantly lower.

Areas under the triacylglycerol curves (Table 3 ) confirmed these observations. Fibre incorporation significantly decreased $0-270 \mathrm{~min}$ areas under the triacylglycerol curves in the presence of BP2 or in the presence of both kinds of wheat-bran preparation. The $0-150$ and $0-210 \mathrm{~min}$ areas under the triacylglycerol curves were also reduced with BP1.

High correlations were found between $0-270 \mathrm{~min}$ insulinaemic mean areas and the percentage of starch hydrolysis after 5,7 (Fig. 2) and $10 \mathrm{~min}(r 0.91, r 0.98, r 0.95$, respectively). No correlations were found between total mean areas under the triacylglycerol curves and in vitro initial and final starch hydrolysis $(5 \mathrm{~min}, r 0.02 ; 7 \mathrm{~min}, r 0.00 ; 120 \mathrm{~min}$, $r 0.31)$.

\section{DISCUSSION}

Total fibre content in beet pulp and wheat bran were 914 and $570 \mathrm{~g} / \mathrm{kg}$ dry matter respectively. The total beet-pulp fibre content in the present study was relatively high compared with the data reported for beet pulp by Michel et al. (1988). The total soluble and insoluble wheat-bran fibre contents were in agreement with other data (Saunders \& Hautala, 1979; Albot \& Boisson, 1985; Prosky et al. 1985). Sugar-beet pulp fibres had a high proportion of soluble fibre (121-196 g/ kg total fibre), whereas wheat bran was mainly a source of insoluble fibre $(930 \mathrm{~g} / \mathrm{kg}$ total fibre).

Grinding did not decrease the total fibre content, but changed the soluble fibre content of beet pulp (from $13.7 \%$ for BP1 to $24.4 \%$ for BP2), whereas this content did not change with WB1 $(7 \cdot 5 \%)$ and WB2 $(8 \cdot 1 \%)$. Beet-pulp insoluble fibres increased significantly and were turned into soluble fibres after grinding.

The action of the sugar-beet fibre was noticeable in the first half of the in vitro starch hydrolysis. This initial decrease of starch hyrolysis could be explained by the presence of pectins and also of cellulose and hemicelluloses (Michel et al. 1988) which could affect the in vitro activity of the pancreatic $\alpha$-amylase (Dunaif $\&$ Schneeman, 1981). The increase of the soluble:insoluble fibre ratio, which results from the grinding, did not modify in vitro starch hydrolysis. 
In contrast to sugar-beet pulp, wheat bran had a positive action on initial starch hydrolysis in the present experiment. These results differed from those of Hansen \& Schulz (1982) who showed an inhibition of the amylase activity and a decrease of in vitro starch degradation with wheat bran. However, the incubation medium used by these authors was poorly enriched with starch $(1 \mathrm{~g} / \mathrm{l})$, and very diluted $(12.5 \mathrm{~g}$ fibre/1). Natural inhibitors of $\alpha$-amylase were held responsible for the inhibition (Snow \& O'Dea, 1981). Wheat bran can also contain endogenous amylases which are released by bran fractionation (Albot \& Boisson, 1985). Indeed, the grain pericarp contains some $\alpha$-amylases (Bradbury et al. 1956) and a $\beta$-amylase $(E C 3.2 .1 .2)$ whose activity depends on the maturity of the grain (Kruger, 1972). A synergistic effect is observed between $\alpha$ and $\beta$-amylases at high concentration levels, the activity of both mixed enzymes being superior to the sum of their respective activities. The endogenous amylases could be responsible for the initial increase of the in vitro starch hydrolysis.

Wheat-bran glucose data showed no significant differences of hyperglycaemia. In accordance with Jenkins et al. (1983), small quantities of wheat bran had no effect on the postprandial peak of glucose. Some authors have seen a positive effect of wheat bran on blood glucose regulation after long-term ingestion of wheat bran (Villaume et al. 1984) or after ingestion of a glucose syrup (Reiser, 1978). Wheat bran may be responsible for a decrease in the glucose absorbed or a slight increase of the peripheral utilization of glucose. However, in acute studies wheat bran seems to act differently. Neither wheat bran nor beet pulp influenced starch digestibility in the small intestine of the pig (Graham et al. 1986). With wheat bran-supplemented diets, insulin levels and areas under the curve were slightly but not significantly increased. This slight increase could be a consequence of a higher rate of glucose absorption not perceptible in glucose levels because of the control action of insulin. The amylases contained in wheat bran could also contribute to this effect.

In accordance with the results of Morgan et al. (1990), it was found that sugar-beet fibre reduced blood glucose levels, but it was only significant with the sugar-beet fibre of the highest particle size. However, sugar-beet fibre had no significant action on the total area under the curve. On the contrary, Morgan et al. (1990) observed a significant reduction of the area under the curve with sugar-beet-supplemented diets, but this effect was not significant on insulin areas. In the present experiment the insulin test, which is usually more sensitive than the glucose test, showed no statistical differences in insulin requirements between sugar-beet fibre and fibre-free diets. This may be due to fat incorporation as $190 \mathrm{~g} / \mathrm{kg}$ total diet which should slow gastric emptying and reduce differences in plasma glucose and insulin levels, but also to gastric inhibitory polypeptide secretion which had been found to be higher when sugar-beet fibre was incorporated into the diet (Morgan et al. 1990).

The reduction by half of the particle size for both dietary fibres had no effect either on in vivo plasma glucose or insulin, or on in vitro starch degradation. Heaton et al. (1988) observed that a decrease in the particle size increased glucose response only with wheat or maize and that the digestibility was affected profoundly only with grains ground into fine flour. Moreover, the range of size of particle must be large enough in order to influence in vitro starch degradation. However, in the present experiment dietary fibre was the only part of the diet which was ground, and was not intimately linked to starch. Grinding did not affect the physico-chemical properties of fibre enough to modify glucose or insulin responses.

Close correlations were found between $30 \mathrm{~min}$ in vitro starch hydrolysis, glycaemic and insulinaemic responses to native and cooked starches in healthy humans (Bornet et al. 1989) and in the pig (Bornet, 1986). The present study confirms high correlations between in vitro initial starch hydrolysis and mean areas under the insulinaemic curves. Thus, the 
initial rate of starch hydrolysis was well-correlated with in vivo insulin areas under the curves at $180 \mathrm{~min}$. The in vitro starch hydrolysis method, first used by Bornet (1986) for native or cooked starches and modified by Leclere et al. (1990), is useful for complex meals containing protein and fat.

Fat was incorporated at the level of $190 \mathrm{~g} / \mathrm{kg}$ diet to simulate human food (maize oil $40 \mathrm{~g}$, lard $150 \mathrm{~g}$ ). It is interesting to observe that fibres can significantly lower the $4.5 \mathrm{~h}$ postprandial triacylglycerolaemia in pigs. The capacity of finely ground wheat bran to reduce the occurrence in the plasma of labelled fatty acids originating from triacylglycerols present in a test meal has been previously demonstrated in the rat (Borel et al. 1989). More recently, addition of fine wheat bran into test meals was shown to decrease the postprandial area under the curve of triacylglycerols in healthy human subjects (Anderson, 1979; Cara et al. 1992). As reported previously, a mechanism underlying such metabolic effects may be a partial inhibition of fat lipolysis and intestinal absorption (Isaksson et al. 1983; Lairon et al. 1985; Borel et al. 1989). Although finely ground wheat bran ( $80 \mu \mathrm{m})$ inhibited the activity of pancreatic lipase more drastically than a coarse preparation $(540 \mu \mathrm{m})$ in vitro (Lairon et al. 1985), either fine or coarse wheat bran comparably lowered postprandial triacylglycerolaemia in the present in vivo study in pigs.

The post-meal effect observed herein on triacylglycerolaemia agrees quite well with data from long-term studies where chronic wheat-bran intake lowered fasting triacylglycerolaemia (Anderson \& Tietyen-Clark, 1986).

Although soluble fibres generally do not display hypotriacylglycerolaemic effects after chronic feeding, some studies in rats report that adding pectins to a test meal could reduce fat assimilation (Isaksson et al. 1983; Judd \& Truswell, 1985). This is also found in the present study done in pigs receiving the beet-pulp fibre preparation. Moreover, the finelyground beet-pulp fibre seemed to be more effective than the coarse beet-pulp fibre. As mentioned earlier, this could result from an increased viscosity of the intestinal content due to the high soluble fibre content of the ground preparation. Thus, it is noteworthy that the $500 \mu \mathrm{m}$ beet-pulp fibre particles, that contained less soluble fibre, exhibited a less marked effect on postprandial triacylglycerolaemia.

Crude or modified fibre properties are able to influence physiological responses. In the present experiment the effects of reduction by half of the particle size were low because of the weak treatment. However, significant modifications of triacylglycerol areas were observed, especially with the finest fibres. Moreover, the in vitro test is valid for studies on insulin responses to diets supplemented with physico-chemically-modified fibres, studies which are necessary to understand the mechanism of fibre action.

\section{REFERENCES}

Albot, G. \& Boisson, J. (1985). Les diverses présentations du son en thérapeutique. Leurs propriétés respectives (Various forms of wheat bran in therapeutics. Their respective properties). Annales de Gastroentérologie et d' Hépatologie 21, 317-319.

Anderson, H., Bosaeus, I., Falkheden, T. \& Melkersson, N. (1979). Scandinavian Journal of Gastroenterology 14, $821-826$.

Anderson, J, W., Story, L., Sieling, B., Chen, W. L., Petro, M. S. \& Story, J. (1984). Hypocholesterolemic effects of oat bran or bean intake for hypocholesterolemic men. American Journal of Clinical Nutrition 40, 1146-1155.

Anderson, J. W. \& Tietyen-Clark, J. (1986). Dietary fiber: hyperlipidemia, hypertension and coronary heart disease. American Journal of Gastroenterology 81, 907-919.

Blackburn, N. A., Redfern, J. S., Jarjis, H., Holgate, A. M., Hanning, I., Scarpello, J. H. B., Johnson, I. T. \& Read, N. W. (1984). The mechanism of action of guar gum in improving glucose tolerance in man. Clinical Science 66, 329-336.

Borel, P., Lairon, D., Senft, M., Chautan, M. \& Lafont, H. (1989). Effect of wheat bran and wheat germ on the digestion and the intestinal absorption of dietary lipids in the rat. American Journal of Clinical Nutrition 49 , 1192-1202.

Borel, P., Martigne, M., Senft, M., Garzino, P., Lafont, H. \& Lairon, D. (1990). Effect of wheat bran and wheat 
germ on the intestinal uptake of oleic acid, monoolein and cholesterol in the rat. Journal of Nutritional Biochemistry 1, 28-33.

Bornet, F. (1986). Etude des relations entre les propriétés physicochimiques de glucides assimilables et leurs effets hyperglycémiants chez l'homme sain ou diabétique et chez le porc (Study of the relations between physicochemical properties of carbohydrates and their hypoglycaemic effects in diabetic or healthy man and in the pig). Thèse de doctorat de troisième cycle de Paris VII, 133 pages.

Bornet, F., Fontvieille, A.-M., Rizkalla, S., Colonna, P., Blayo, A., Mercier, C. \& Slama, G. (1989). Insulin and glycemic responses in healthy humans to native starches processed in different ways: correlation with in vitro alpha-amylolysis. American Journal of Clinical Nutrition 50, 315-323.

Bradbury, D., MacMasters, M. M. \& Cull, I. M. (1956). Structure of the mature wheat kernel. II. Microscopic structure of pericarp, seed coat, and other coverings of the endosperm and germ of hard red winter wheat. Cereal Chemistry 33, 342 .

Buccolo, G. \& David, H. (1973). Quantitative determination of serum triglycerides by the use of enzymes. Clinical Chemistry 19, 476-482.

Cara, L., Dubois, C., Borel, P., Armand, M., Senft, M., Portugal, H., Pauli, A. M., Bernard, P. M. \& Lairon, D. (1992). Effects of oat bran, rice bran, wheat fiber and wheat germ on postprandial lipemia in healthy adults. American Journal of Clinical Nutrition 55, 81-88.

Cherbut, C., Salvador, V., Barry, J.-L., Doulay, F. \& Delort-Laval, J. (1991). Dietary fibre effects on intestinal transit in man: involvement of their physicochemical and fermentative properties. Food Hydrocolloids 5, $15-22$.

Dunaif, G. \& Schneeman, B. O. (1981). The effect of dietary fiber on human pancreatic enzyme activity in vitro. American Joumal of Clinical Nutrition 34, 1034-1035.

Ebeling, P., Yki-Jarvinen, H., Aro, A., Helve, E., Sinisalo, M. \& Koivisto, V. A. (1988). Glucose and lipid metabolism and insulin sensitivity in type 1 diabetes: the effect of guar gum. American Journal of Clinical Nutrition 48, 98-103.

Edwards, C. A., Blackburn, N. A., Craigen, L., Davidson, P., Tomlin, J., Sugden, K., Johnson, I. T. \& Read, N. W. (1987). Viscosity of food gums determined in vitro related to their hypoglycemic actions. American Journal of Clinical Nutrition 46, 72-77.

Gallaher, D. \& Schneeman, B. O. (1985). Effect of dietary cellulose on site of lipid absorption. American Journal of Physiology 249, G184-G191.

Gee, J. M., Blackburn, N. A. \& Johnson, I. T. (1983). The influence of guar gum on intestinal cholesterol transport in the rat. British Journal of Nutrition 50, 215-224.

Goodlad, J. S. \& Mathers, J. C. (1991). Digestion by pigs of non-starch polysaccharides in wheat and raw peas (Pisum sativum) fed in mixed diets. British Journal of Nutrition 65, 259-270.

Graham, H., Hesselman, K. \& Aman, P. (1986). The influence of wheat bran and sugar-beet pulp on the digestibility of dietary components in a cereal-based diet. Journal of Nutrition 116, 242-251.

Hamberg, O., Rumessen, J. J. \& Gudman-Hoyer, E. (1989). Inhibition of starch absorption by dietary fibre. A comparative study of wheat bran, sugar-beet fibre, and pea fibre. Scandinavian Journal of Gastroenterology $\mathbf{2 4}$, $103-109$

Hansen, W. E. \& Schulz, G. (1982). The effect of dietary fibre on pancreatic amylase activity in vitro. Hepatogastroenterology 29, 157-160.

Heaton, K. W., Marcus, S. N., Emmett, P. M. \& Bolton, C. H. (1988). Particle size of wheat, maize, and oat test meals: effects on plasma glucose and insulin responses and on the rate of starch digestion in vitro. American Journal of Clinical Nutrition 47, 675-682.

Isaksson, G., Asp, N.-G. \& Ihse, I. (1983). Effect of dietary fiber on pancreatic enzyme activities of ileostomy evacuate and on excretion of fat and nitrogen in the rat. Scandinavian Journal of Gastroenterology 18, 417-423.

Jenkins, D. J. A., Wolever, T. M. S., Jenkins, A. L., Lee, R., Wong, G. S. \& Josse, R. (1983). Glycemic response to wheat products: reduced response to pasta but no effect of fiber. Diabetes Care 6, 155-159.

Jenkins, D. J. A., Wolever, T. M. S., Leeds, A. R., Gassul, M. A., Haismam, P., Dilawari, J., Goff, D. V., Metz, G. L. \& Alberti, K. G. M. M. (1978). Dietary fibres, fibre analogues, and glucose tolerance: importance of viscosity. British Medical Journal 1, 1392-1394.

Judd, P. A. \& Truswell, A. S. (1985). The hypocholesterolemic effects of pectin in rats. British Journal of Nutrition 53, 409-425.

Karlstrom, B., Nydahl, M. \& Vessby, B. (1989). Dietary habits and effects of dietary advice in patients with type 2 diabetes. Results from a one-year intervention study. European Journal of Clinical Nutrition 43, 59-68.

Kay, R. M. \& Truswell, A. S. (1977). Effect of citrus pectin on blood lipids and fecal steroid excretion in men. American Journal of Clinical Nutrition 30, 171-175.

Kruger, J. E. (1972). Changes in the amylases of hard red spring wheat during growth and maturation. Cereal Chemistry 47, 79.

Lairon, D., Lafont, H., Vigne, L., Nalbone, G., Leonardi, J. \& Hauton, J. C. (1985). Effects of dietary fibers and cholestyramine on the activity of pancreatic lipase in vitro. American Journal of Clinical Nutrition 49, 629-638.

Leclere, C., Cherbut, C., Guillon, F. \& Champ. M. (1990). The effect of soluble fibre content of beet pulp on the in vitro alpha-amylolysis of a semi-synthetic meal. Sciences des Aliments 10, 309-315.

Leveille, G. A. \& Sauberlich, H. E. (1966). Mechanism of the cholesterol-depressing effect of pectin in the cholesterol-fed rat. Journal of Nutrition 88, 209. 
Michel, F., Thibault, J. F., Barry, J. L. \& De Baynast, R. (1988). Preparation and characterisation of dietary fibre from sugar beet pulp. Journal of the Science of Food and Agriculture 42, 77-85.

Morgan, L. M., Tredger, J. A., Wright, J. \& Marks, V. (1990). The effect of soluble and insoluble-fibre supplementation on postprandial glucose tolerance, insulin and gastric inhibitory polypeptide secretion in healthy subjects. British Journal of Nutrition 64, 103-110.

Peters, L. E., Walker, L. P., Wilson, D. B. \& Irwin, D. C. (1991). The impact of initial particle size on the fragmentation of cellulose by the cellulases of Thermomonospora fusca. Bioresource Technology 35, 313-319.

Prosky, L., Asp, N.-G., Furda, I., Devries, J. W., Schweizer, T. F. \& Harland, B. F. (1985). Determination of total dietary fiber in foods and food products: collaborative study. Association of Official Analytical Chemists. Journal 68 (4), 677-679.

Prosky, L., Asp, N. G., Furda, I., Schweizer, T. \& De Vries, J. W. (1988). Determination of insoluble, soluble and total dietary fiber in foods and food products. Association of Official Analytical Chemists. Journal 71, 1017-1023.

Reiser, S. (1978). The role of cereal fiber in human nutrition and health: glucose tolerance and diabetes. In Proceedings of 10th National Conference on Wheat Utilization Research, pp. 39-50. Berkeley, California: Science and Education Administration.

Saunders, R. M. \& Hautala, E. (1979). Dietary fiber evaluation of wheat products by in vitro and in vivo methods. In Dietary Fibers: Chemistry and Nutrition, pp. 79-93 [S. E. Inglett and S. I. Falkehag, editors]. London: Academic Press Inc. Ltd.

Schneeman, B. O. (1978). Effect of plant fiber on lipase, trypsin and chymotrypsin activity. Journal of Food Science 43, 634-635.

Snow, P. \& O'Dea, K. (1981). Factors affecting the rate of hydrolysis of starch in food. American Journal of Clinical Nutrition 34, 2721-2727.

Villaume, C., Beck, B., Gariot, P., Desalme, A. \& Debry, G. (1984). Long-term evolution of the effect of bran ingestion on meal-induced glucose and insulin responses in healthy man. American Journal of Clinical Nutrition 40, $1023-1026$.

Wyman, J. B., Heaton, K. W. \& Maning, A. P. (1976). Laxative effect of all-bran. British Medical Journal ii, 944. 